9. McDonagh AF, Assisi F 1972 The ready isomerization of bilirubin $2 \mathrm{X} \alpha$ in aqueous solution. Biochem J 129:797

10. McDonagh AF, Palma LA 1980 Hepatic excretion of circulating bilirubin photoproducts in the Gunn rat. J Clin Invest 66:1 182

11. McDonagh AF, Palma LA, Lightner DA 1982 Phototherapy for neonatal jaundice. Stereospecific and regioselective photoisomerization of bilirubin bound to human serum albumin and NMR characterization of intramolecularly cyclized photoproducts. J Am Chem Soc 104:6867

12. McDonagh AF, Palma LA, Trull FR, Lightner DA 1982 Phototherapy for neonatal jaundice. Configurational isomers of bilirubin. J Am Chem Soc 104:6865

13. Onishi S, Isobe K, Itoh S, Kawade N, Sugiyama S 1980 Demonstration of a geometric isomer of bilirubin IX $\alpha$ in the serum of a hyperbilirubinemic newborn infant and the mechanism of jaundice phototherapy. Biochem $J$ 190:533

14. Onishi S, Kawade N, Itoh S, Isobe K, Sugiyama S, Hashimoto T, Narita H 1981 Kinetics of biliary excretion of the main two bilirubin photoproducts after injection into Gunn rats. Biochem J 198:107

15. Sisson TCR, Kendall N, Shaw A, Kechavarz-Oliai L 1972 Phototherapy of neonatal jaundice in the newborn. II. Effect of various light intensities. J Pediatr 81:35

16. Tan KL 1977 The nature of the dose-response relationship of phototherapy for neonatal hyperbilirubinemia. J Pediatr 90:448

17. Tan KL 1982 The pattern of bilirubin response to phototherapy for neonatal hyperbilirubinemia. Pediatr Res 16:670

18. Vecchi C, Donzelli GP, Migliorini MG, Sbrana G 1983 Green light in phototherapy. Pediatr Res 17:461

19. Warshaw JB, Gagliardi RN, Patel A 1980 A comparison of fluorescent and nonfluorescent light sources for phototherapy. Pediatrics 65:795

20. Requests for reprints should be addressed to: John F. Ennever, Ph.D., M.D., Department of Pediatrics, Rainbow Babies and Childrens Hospital, 2101 Adelbert Road, Cleveland, $\mathrm{OH} 44106$.

21. This research was supported by the United States Public Health Service through Grants CA-23692, AM-26307, and AM-11275, by Research Career Development Award IK0-0043 to W. T. S., and by a grant from the Board of Trustees of Rainbow Babies and Childrens Hospital.

\title{
A New Form of Insulin Resistance with Growth Retardation, Fatty Liver, and Hypogonadotropic Hypogonadism
}

\author{
ETSURO TOKUHIRO, HEATHER DEAN, JEREMY WINTER, JAMES C. HAWORTH \\ YASUO IMAI, AND HENRY G. FRIESEN ${ }^{(39)}$ \\ Departments of Physiology [E.T., Y.I., H.G.F.] and Pediatrics [H.D., J.W., J.C.H.], Faculty of Medicine, \\ University of Manitoba, Winnipeg, Manitoba, Canada R3E oW3
}

\section{Summary}

A 17-year-old boy presented with growth retardation, marked hepatomegaly, and sexual infantilism. Elevated fasting serum insulin levels and a blunted hypoglycemic response to exogenous insulin (up to $0.35 \mathrm{unit} / \mathrm{kg}$ ) demonstrated severe insulin resistance. Neither anti-insulin nor anti-insulin receptor antibodies were present. The molecular size of his circulating insulin and its binding to IM-9 lymphocytes was normal. Despite high circulating insulin values, both erythrocytes and cultured skin fibroblasts showed normal insulin binding capacity and affinity. Tissue responsiveness was examined by measuring the insulin-induced increase in 2-deoxyglucose uptake into fibroblasts. Although the basal glucose transport rate was slightly lower than that of controls, the insulin-induced increase was normal. However, the normal increase in thymidine incorporation in response to insulin was blunted, as were the thymidine incorporation responses to epidermal growth factor and fibroblast growth factor. These studies demonstrate the possible existence of a new form of postinsulin receptor defect as a cause of insulin resistance, but underscore the difficulty that exists in defining the exact nature of the defect in these disorders.

IRI, immunoreactive insulin

\section{Abbreviations}

$\mathrm{G}$, gonads

PH, pubic hair

EGF, epidermal growth factor

hFGF, human fibroblast growth factor

Hepes, 4-(2-hydroxyethyl)-1-piperazineethanesulfonic acid

2-DG, 2-deoxyglucose
Insulin resistance, a clinical syndrome characterized by a blunted response to endogenous insulin, with or without a similar poor response to administered insulin, causes some degree of hyperglycemia as well as other more variable clinical features (2, 26 ). Its etiology may include production of an abnormal insulin molecule $(6,33)$, the presence of circulating antagonists to insulin such as anti-insulin or anti-insulin receptor antibodies and con tra-insulin factors $(5,25,36)$, abnormally rapid degradation of insulin (27), quantitative (32) and qualitative $(18,35)$ abnormalities of the insulin receptors (18), and poorly defined defects in post-receptor mechanisms $(19,22)$.

This report describes a 17-year-old boy with an unusual form of insulin resistance in whom extensive studies point to a postreceptor defect but have failed to define the exact nature of the abnormality.

\section{CASE REPORT}

A 17-year-old Caucasian boy was referred for evaluation of hepatomegaly and growth retardation. He was the product of an uneventful 37-week pregnancy with a birth weight of $2.2 \mathrm{~kg}$. He showed no dysmorphic features other than bilateral cryptorchidism. There was no family history of consanguinity or diabetes. The midparental stature was $161.3 \mathrm{~cm}$. His height and weight growth was below but parallel to the third percentile throughout childhood. Orchidopexy was carried out at 6 years of age; at age 8 , his serum follicle-stimulating hormone, luteinizing hormone, and testosterone values were in the normal prepubertal range. At age 15, hepatomegaly was first noticed. Biopsy of the liver demonstrated severe fatty metamorphosis; there was appreciable glycogen content and moderate periportal fibrosis with some bile 
duct reduplication and mild mixed inflammatory cell infiltration. The exact diagnosis was uncertain, but chronic active hepatitis was considered. Prednisone (7.5-60 mg/day) was administered for 1 year with no effect on liver size. Other studies had excluded $\alpha-1$ antitrypsin deficiency, Wilson's disease, glycogen storage disease, galactosemia, fructose intolerance, cystic fibrosis, chronic viral infection, or an immunodeficiency disorder.

On physical examination at age 174/12 years, he was short (height, $146.5 \mathrm{~cm}$; weight, $41.9 \mathrm{~kg}$ ), and had a distended abdomen and thin extremities. His blood pressure was $110 / 60 \mathrm{~mm} \mathrm{Hg}$ and pulse was 84 beats $/ \mathrm{min}$. A firm liver edge was palpable $9 \mathrm{~cm}$ below the right costal margin. There was no ascites and the spleen was not palpable. His penis and testes were of infantile size but there was a small amount of pubic hair (Tanner stage $\mathrm{G}_{1} \quad \mathrm{PH}_{2}$ ). There was no evidence of acanthosis nigricans or lipodystrophy. His bone age was 14.5 years. Routine blood counts, serum electrolytes, creatinine, urea nitrogen, and serum lipoproteins were within normal limits. Blood glucose was 129 $\mathrm{mg} / \mathrm{dl}$. Liver function tests showed abnormal enzyme values (serum aspartate transaminase, $435 \mathrm{U} /$ liter; normal range, 0-50 $\mathrm{U} /$ liter; alanine transaminase, $685 \mathrm{U} /$ liter; normal range, $10-40$ $\mathrm{U} /$ liter; lactate dehydrogenase, $455 \mathrm{U} /$ liter; normal range, $100-$ $225 \mathrm{U} /$ liter), but his serum bilirubin was normal. Anti-DNA antibody was in the normal range and antinuclear factor was negative. The urinalysis was normal except for a small amount of glucose; there was no ketonuria.

Insulin resistance became apparent during testing for possible growth hormone deficiency. In response to IV insulin (doses as large as $0.2 \mathrm{U} / \mathrm{kg}$ ), no effect on blood glucose was observed; an additional injection of $0.15 \mathrm{U} / \mathrm{kg}$ of insulin $30 \mathrm{~min}$ after the first elicited only a slight decline of blood glucose from 100 to $73 \mathrm{mg} /$ dl. His fasting blood glucose ranged from $93-120 \mathrm{mg} / \mathrm{dl} \mathrm{with}$ corresponding fasting serum IRI levels from 84-214 $\mu \mathrm{U} / \mathrm{ml}$ (normal less than $15 \mu \mathrm{U} / \mathrm{ml}$ ). Following oral administration of glucose $(70 \mathrm{~g})$, serum glucose values were $429 \mathrm{mg} / \mathrm{dl}$ at $30 \mathrm{~min}$, $394 \mathrm{mg} / \mathrm{dl}$ at $60 \mathrm{~min}, 318 \mathrm{mg} / \mathrm{dl}$ at $120 \mathrm{~min}$, and $220 \mathrm{mg} / \mathrm{dl}$ at $180 \mathrm{~min}$. Serum IRI levels remained above $240 \mu \mathrm{U} / \mathrm{ml}$ throughout the oral glucose tolerance test. The results of other endocrine studies are listed in Table 1. Samples of serum, red blood cells, and skin were taken for further evaluation of insulin responses. During 4 years of follow-up, there was no significant change in his fasting serum IRI levels, glucose tolerance, or liver size. Depotestosterone, $200 \mathrm{mg}$ IM monthly, has resulted in adequate development of secondary sex characteristics (Tanner stage $G_{4}$ $\mathrm{PH}_{4}$ ) and maturation of his skeletal age to 17 years.

\section{MATERIALS AND METHODS}

Materials included: $\left[\right.$ methyl $\left.-{ }^{3} \mathrm{H}\right]$ thymidine $(49 \mathrm{Ci} / \mathrm{mmol})$ and 2-deoxy-D-[1- $\left.{ }^{14} \mathrm{C}\right]$ glucose $(57 \mathrm{mCi} / \mathrm{mmol}$, Amersham); 2-deoxy-
D-glucose (Sigma); fetal bovine serum, Dulbecco's modified Eagle's medium and penicillin-streptomycin solution (Gibco); and highly purified crystalline porcine insulin $(24.4 \mathrm{U} / \mathrm{mg}$, Connaught Laboratories). Mouse EGF was prepared from male mouse submaxillary glands according to the method of Savage: and Cohen (30), and hFGF was prepared from human brain (21).

Studies of the Circulating Insulin Molecule and of Insulin Antagonists. The ratio of proinsulin to insulin in the patient's serum was evaluated by radioimmunoassay following separation of the two components by Sephadex G-50 superfine gel filtration. The ability of the insulin in the peak insulin fraction from this column to bind to a known effective insulin receptor was assessed using IM-9 lymphocytes (8). Anti-insulin receptor antibodies in serum were measured by the method of Flier et al. (5).

Studies of Insulin Receptor. ${ }^{125}$ I-insulin binding to erythrocytes. Insulin was iodinated by the chloramine $T$ method (12) to a specific activity of $100-140 \mu \mathrm{Ci} / \mu \mathrm{g}$. ${ }^{125} \mathrm{I}$-Insulin binding to erythrocytes was determined in two separate blood samples from the patient, and six control samples from healthy male adults and two samples from other patients with insulin resistance by the method of Gambhir et al. (7). The erythrocytes $\left(1.6 \times 10^{9}\right)$ were incubated with $2 \times 10^{4} \mathrm{cpm}{ }^{125} \mathrm{I}$-insulin $(0.1 \mathrm{ng})$ and varying amounts of cold insulin in a total volume of $0.5 \mathrm{ml}$.

${ }^{125} \mathrm{I}$-insulin binding to cultured fibroblasts. Fibroblast cultures were established using skin from the patient's abdomen and from skin biopsies of the same region taken during surgery from four normal male control subjects of a similar age. The explants were grown in Dulbecco's modified Eagle's medium supplemented with $50 \mathrm{U} / \mathrm{ml}$ of penicillin, $50 \mu \mathrm{g} / \mathrm{ml}$ of streptomycin, and $10 \%$ fetal bovine serum in an atmosphere of $5 \% \mathrm{CO}_{2}, 95 \%$ air at $37^{\circ} \mathrm{C}$. Medium was changed twice a week and the cultured fibroblasts were used at confluency after $6-12$ passages. It was noted that the doubling time of the patient's fibroblasts was $150 \%$ that of the control fibroblasts. Eighteen hours prior to assay, the medium was replaced with new medium containing $0.1 \%$ fetal bovine serum.

${ }^{125}$ I-Insulin binding to cultured fibroblasts in situ was determined by the method of Schilling et al. (32) with minor modifications. Confluent fibroblasts $\left(7-9 \times 10^{5}\right.$ cells $/ 35-\mathrm{mm}$ dish) were incubated with $4 \times 10^{5} \mathrm{cpm}$ of ${ }^{125}$ I-insulin and varying amounts of cold hormone in $1 \mathrm{ml}$ buffer $(0.1 \mathrm{M}$ Hepes, $0.12 \mathrm{M} \mathrm{NaCl}, 1.2$ $\mathrm{mM} \mathrm{MgSO}_{4}, 2.5 \mathrm{mM} \mathrm{KCl}, 10 \mathrm{mM}$ glucose, $10 \mathrm{mg}$ bovine serum albumin, $\mathrm{pH} 8.0$ ) at $15^{\circ} \mathrm{C}$ for $5 \mathrm{~h}$. After incubation, cells were washed three times with cold buffer and dissolved with $0.1 \mathrm{~N}$ $\mathrm{NaOH}$ containing $0.1 \%$ Triton X-100. Radioactivity of the lysates was counted in a scintillation counter.

Studies of Post-receptor Insulin Action. 2-Deoxyglucose incorporation into fibroblasts. 2-DG incorporation into fibroblasts was studied by the method of Schilling et al. (32), but using confluent

Table 1. Serum hormone concentrations and responses to stimulation tests*

\begin{tabular}{|c|c|c|c|c|}
\hline & $\begin{array}{l}\text { Basal } \\
\text { value }\end{array}$ & $\begin{array}{l}\text { Peak } \\
\text { value }\end{array}$ & Stimulation by & Interpretation \\
\hline Thyroxine $(\mu \mathrm{g} / \mathrm{dl})$ & 9.9 & & & Normal \\
\hline Triiodothyronine (ng/dl) & 8.3 & & & Normal \\
\hline $\mathrm{TSH}(\mu \mathrm{U} / \mathrm{ml})$ & 1 & 10 & TRH $(200 \mu \mathrm{g})$ & Blunted \\
\hline Prolactin $(\mathrm{ng} / \mathrm{ml})$ & 3.4 & 10 & $\mathrm{TRH}$ & Normal \\
\hline \multirow[t]{2}{*}{ Growth hormone (ng/ml) } & 1.0 & 2.6 & Arginine $(0.5 \mathrm{~g} / \mathrm{kg})$ & Blunted \\
\hline & 0.8 & 5.5 & 1-dopa Propranolol & Blunted \\
\hline FSH $(\mu \mathrm{g}$ LER $907 / \mathrm{dl})$ & 19 & 31 & LH-RH $(100 \mu \mathrm{g})$ & Normal basal; normal response \\
\hline $\mathrm{LH}(\mu \mathrm{g}$ LER907/dl) & 18 & 21 & LH-RH & Elevated basal; blunted response \\
\hline Testosterone (ng/ml) & 24 & 77 & hCG $(2000$ IU IM $)$ daily $\times 3$ & Prepubertal \\
\hline Cortisol $(\mu \mathrm{g} / \mathrm{dl})$ & 19 & & & Normal \\
\hline Glucagon $(\mathrm{pg} / \mathrm{ml})$ & 36 & & & Normal \\
\hline Basic somatomedin $\dagger(\mathrm{U} / \mathrm{ml})$ & 0.81 & & & Normal \\
\hline
\end{tabular}

* TSH, thyroid-stimulating hormone; LH-RH, luteinizing hormone-releasing hormone; TRH, thyrotropin-releasing hormone; FSH, folliclestimulating hormone; hCG, human chorionic gonadotropin. Normal basal range for male age 16-18: FSH, 11.5-27.0 $\mu \mathrm{g} / \mathrm{dl} ;$ and $\mathrm{LH}, 2.4-5.8 \mu \mathrm{g} / \mathrm{dl}$.

$\dagger$ Serum basic somatomedin level was determined by Dr. R. M. Bala (University of Saskatchewan) (1). 
cell cultures instead of trypsinized cell suspension. The fibroblasts were preincubated in Krebs-Ringer phosphate buffer in the presence or absence of insulin $(100 \mathrm{ng} / \mathrm{ml})$ at $37^{\circ} \mathrm{C}$ for $20 \mathrm{~min} ; 50 \mu \mathrm{l}$ of $2 \mathrm{mM}\left[{ }^{14} \mathrm{C}\right] 2-\mathrm{DG}(2 \mu \mathrm{Ci} / \mu \mathrm{mol})$ was then added and further incubation was carried out for 5 or $10 \mathrm{~min}$. The cells were washed rapidly in cold buffer three times to terminate the reaction, and solubilized in $0.1 \mathrm{~N} \mathrm{NaOH}$ containing $0.1 \%$ Triton $\mathrm{X}-$ 100 and Biofluor, and the lysate was counted in a scintillation counter.

Thymidine incorporation into fibroblasts. Fibroblasts were grown to confluency and then replated in $35-\mathrm{mm}$ dishes at a concentration of $0.4-0.8 \times 10^{5}$ cells/dish. After $24 \mathrm{~h}$, the maintenance growth medium containing $10 \%$ fetal bovine serum was replaced with medium containing $0.05 \%$ fetal bovine serum; the cells were incubated in this medium for $48 \mathrm{~h}$ prior to assay to reduce DNA synthesis and cell replication to a minimum. Thymidine incorporation into fibroblasts was determined by the method of Harley et al. (14). In a preliminary study, maximum thymidine incorporation was found after the patient's fibroblasts and control fibroblasts had been incubated with medium containing $10 \%$ fetal bovine serum for 24 and $20 \mathrm{~h}$, respectively. Therefore, the cells were incubated for time periods ranging from $5-29 \mathrm{~h}$ with 0.1 serum-free medium containing $0.1 \%$ bovine serum albumin, and varying concentrations of dialyzed fetal bovine serum, EGF, or human FGF-like substance. A small volume of serum-free medium containing $\left[{ }^{3} \mathrm{H}\right]$ thymidine $(0.2$ $\mu \mathrm{Ci} / \mathrm{dish}$ ) was then added and incubation continued for $30 \mathrm{~min}$. The assay was terminated by washing the cells once in cold saline and twice in $5 \%$ trichloroacetic acid. The cells were dissolved in $0.1 \mathrm{~N} \mathrm{NaOH}$ and counted in a scintillation counter.

\section{RESULTS}

Studies of the Circulating Insulin Molecule and of Potential Insulin Antagonists. Proinsulin represented approximately $25 \%$ of the total circulating insulin. Radioreceptor assay of the peak insulin fraction showed activity comparable to that determined by radioimmunoassay. No circulating anti-insulin or anti-insulin receptor antibodies were found.

Studies of the Insulin Receptor on Erythrocytes and Cultured Fibroblasts. Scatchard plot analysis (31), shown in Figure 1, demonstrated that, despite the high circulating insulin levels, the insulin-binding capacity and affinity of the erythrocyte receptors were within the normal adult range. In contrast, two other patients with insulin resistance (cases 1 and 2) showed reduced insulin-binding capacity.

The results of ${ }^{125}$ I-insulin binding to the cultured fibroblasts are shown in Figure 2. These studies indicate that the ability of the patient's fibroblasts to bind insulin was also normal.

Studies on Post-receptor Insulin Action. Insulin effect of 2 deoxyglucose uptake in cultured fibroblasts. The effect of insulin upon the ability of fibroblasts from the patient and one of the normal control subjects to take up $\left[{ }^{14} \mathrm{C}\right] 2-\mathrm{DG}$ is shown in Figure 3. Basal 2-DG uptake (without insulin) in the patient's fibroblasts was somewhat lower than in control fibroblasts, but insulin (100 $\mathrm{ng} / \mathrm{ml}$ ) enhanced uptake to a degree comparable to the increase in control fibroblasts. The patient's fibroblasts also demonstrated a variable increase in 2-deoxyglucose uptake in response to insulin at concentrations lower than $100 \mathrm{ng} / \mathrm{ml}$. Maximal acceleration of 2-DG uptake in both the patient's and control fibroblasts was found at concentrations between $100 \mathrm{ng} / \mathrm{ml}$ and $1 \mu \mathrm{g} /$ $\mathrm{ml}$ of insulin. This experiment was repeated four times with separate passages of the patient's cells and control fibroblasts from different subjects. The mean $( \pm \mathrm{SD})$ basal uptake of the patient's cells was $1.50 \pm 0.16 \mathrm{nmol} 2-\mathrm{DG} / 10^{6}$ cells $/ 10 \mathrm{~min}$, while that of the controls was $2.46 \pm 0.54$. After exposure to insulin $(100 \mathrm{ng} / \mathrm{ml})$, the uptake was $2.16 \pm 0.14$ in the patient's cells and $3.64 \pm 0.44$ in the controls.

Thymidine incorporation into fibroblasts. The effects of dialyzed fetal bovine serum, insulin, EGF, and hFGF-like substance on thymidine uptake in the patient's fibroblasts and

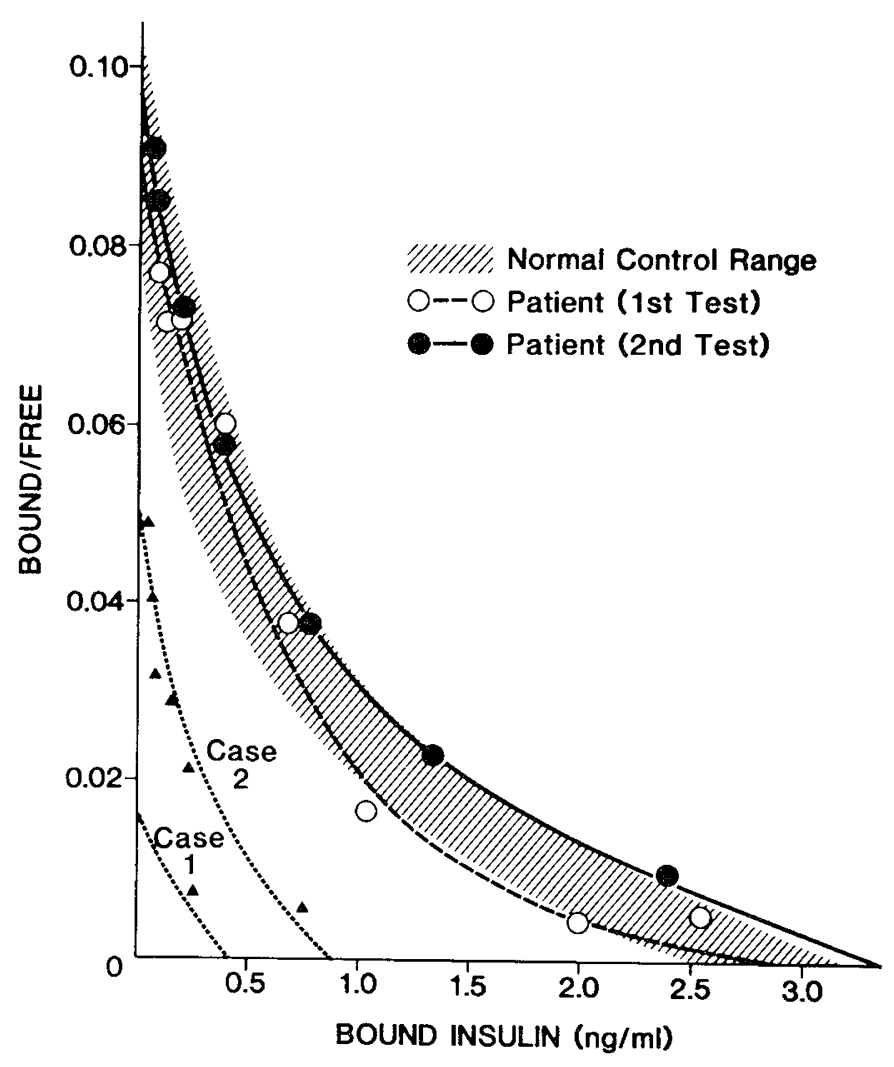

Fig. 1. Scatchard plot analysis of insulin binding to erythrocytes. ${ }^{125} \mathrm{I}-$ Insulin binding to circulating erythrocytes (specific binding for $3.2 \times 10^{4}$ cells) was determined using the method of Gambhir et al. (7). The shaded area represents the normal range derived from six healthy adult males. Case 1 is a patient with acanthosis nigricans and case 2 is a 14-year-old prepubertal obese female $(150 \%$ of ideal weight), both of whom are insulin-resistant. $\longrightarrow$ and $\mathrm{O}_{--} \mathrm{O}$ represent results obtained on patient's erythrocytes in two separate experiments.

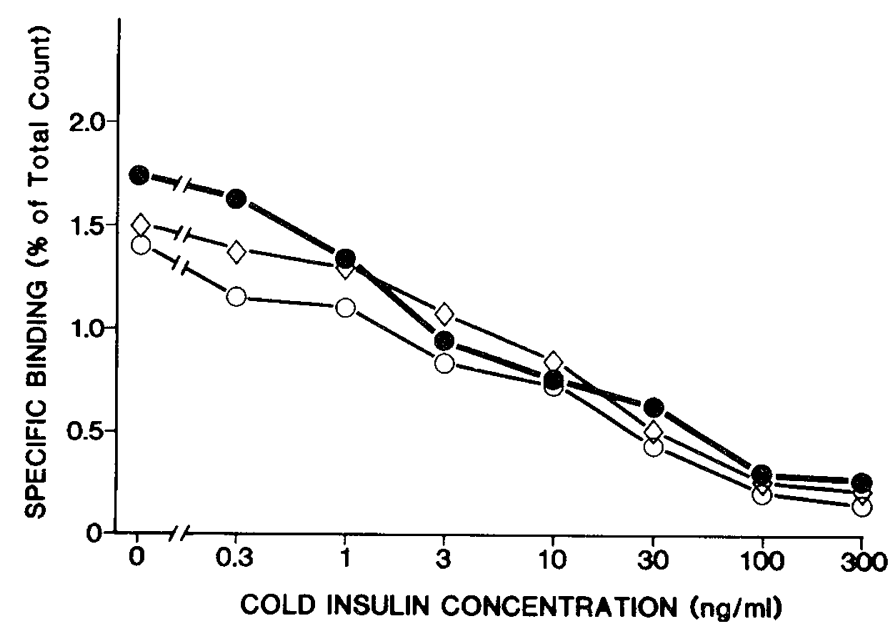

Fig. 2. ${ }^{125}$ I-insulin binding to cultured fibroblasts. The results are expressed as specific binding for $1 \times 10^{6}$ cells. Each point represents mean of triplicate assays. Specific binding was calculated as the difference between total radioactivity bound and nonspecific binding in the presence of $5 \mu \mathrm{g} / \mathrm{ml}$ insulin (results not shown). $\diamond \longrightarrow \diamond$ and $\bigcirc-O$, two control subjects.

control fibroblasts is shown in Figure 4. A high concentration of insulin $(10 \mu \mathrm{g} / \mathrm{ml})$ increased thymidine incorporation into the control fibroblasts 9 -fold, but elicited only a 2.4 -fold rise in the patient's fibroblasts. A lesser response to $\left[{ }^{3} \mathrm{H}\right]$ thymidine incor- 


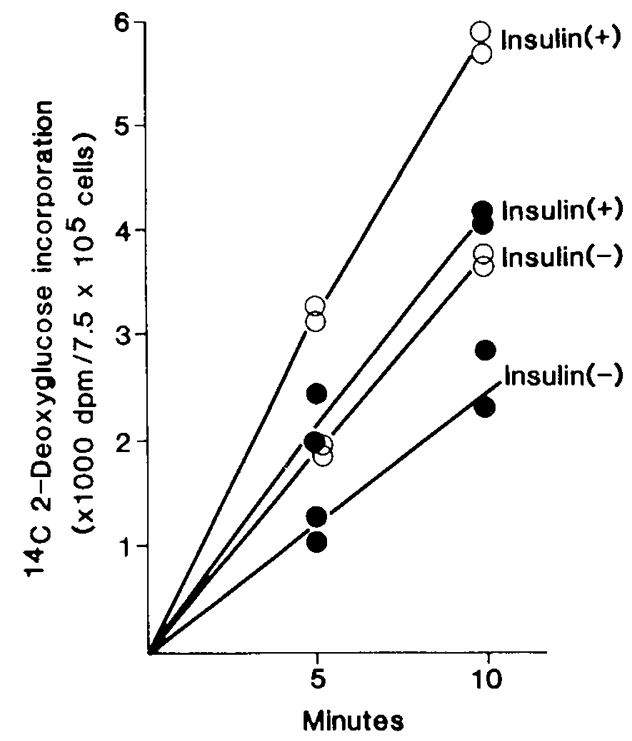

Fig. 3. Insulin effect of 2-deoxyglucose uptake by fibroblasts. The uptake of $\left[{ }^{14} \mathrm{C}\right] 2$-deoxyglucose with or without insulin $(100 \mathrm{ng} / \mathrm{ml})$ by fibroblasts from the patient $(-)$ ) and a control subject $(\mathrm{O}-\mathrm{O})$ is shown.

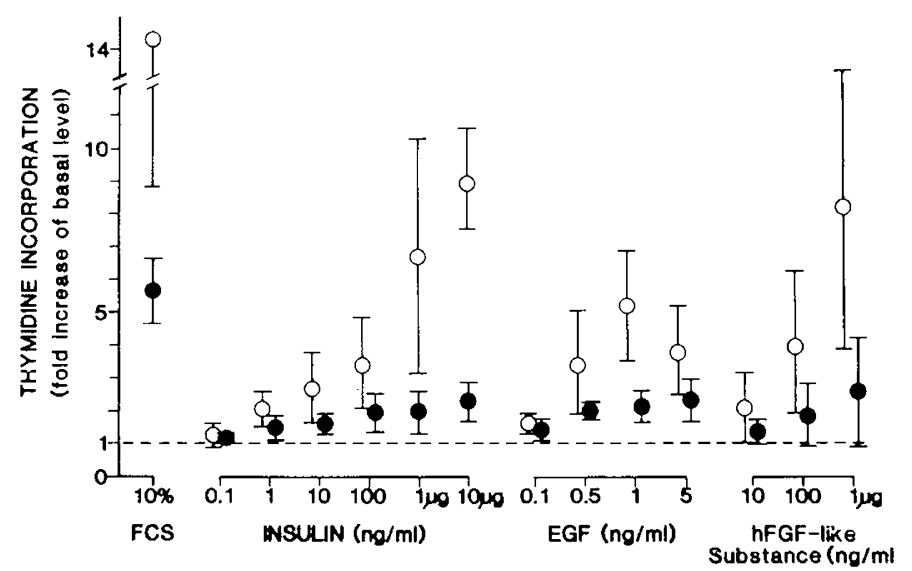

Fig. 4. The effects of fetal bovine serum, insulin. EGF, and hFGFlike substance on $\left[{ }^{3} \mathrm{H}\right]$ thymidine incorporation into fibroblasts. Each point represents the mean $\pm \mathrm{SD}$ of three assays: each assay included fibroblasts from four control subjects $(O)$ and from the patient at three different generations $(\bullet)$. The response of the patient's fibroblasts to insulin at $10 \mu \mathrm{g} / \mathrm{ml}$ is significantly lower than in control fibroblasts $(P<$ 0.01 ).

poration in the patient's fibroblasts was also observed in response to dialyzed fetal bovine serum, EGF, and hFGF.

\section{DISCUSSION}

The clinical features of this patient differ from those seen in other reported forms of insulin resistance. No clinical evidence of hypersecretion of any hormonal insulin antagonist such as growth hormone, thyroxine, cortisol, or glucagon was found. There were no features of congenital lipodystrophy (16) or acanthosis nigricans $(5,18)$ and no evidence of any other disease known to be associated with insulin resistance such as obesity, leukemia, collagen vascular disease, ataxia telangiectasia, or uremia (2). Although his liver showed some cirrhotic changes, the degree of insulin resistance was not in keeping with that observed in cirrhosis $(11,17)$. Some patients with liver disease may show impaired degradation of circulating insulin (17) or a decreased number of insulin receptors (11) but these were not present in our patient. The fatty infiltration of his liver was most likely a result of abnormal glucose metabolism, as is seen in congenital lipodystrophy (28) and poorly controlled insulin-dependent diabetes mellitus (13), rather than the cause of his insulin resistance.

Since we were unable to define any clinical syndrome known to be associated with insulin resistance, we attempted to describe it in molecular terms. There was no biochemical evidence of any circulating hormonal or immunological insulin or insulin receptor antagonists. We evaluated the structural integrity of the patient's insulin molecule by fractionating his serum by gel filtration. Since the fraction of proinsulin present in his serum was normal (6), we concluded that there was no intracellular abnormality of processing of proinsulin to insulin. The amount of immunoassayable insulin in the insulin peak was comparable to the insulin capable of competing for binding sites on human IM-9 lymphocytes. Thus, on the basis of normal molecular size and binding in two unique binding assays, we have inferred normal structure and bioactivity of his circulating insulin.

We observed normal insulin-binding capacity and affinity of his erythrocytes and cultured fibroblasts. It is of interest that receptor capacity in this prepubertal boy was the same as in adult controls despite circulating insulin levels 10 -fold higher than normal since both childhood and hyperinsulinism are normally associated with decreased receptor number. This finding suggests a failure of down-regulation of the insulin receptor and is compatible with a post-receptor defect (12).

The observation that our patient's fibroblasts demonstrated normal insulin-stimulated glucose uptake provides further evidence that the defect is not an intrinsic receptor abnormality but rather a defect distal to the coupling between the insulin-receptor complex and the glucose transport system. We did however find some impairment of glucose transport since both the absolute levels of basal and insulin-stimulated glucose uptake were lower than in the controls, suggesting a defect in the glucose transport mechanism itself. Our findings are similar to those described recently by Kaplowitz and d'Ercole (19) in an infant with leprechaunism, but are in direct contrast to those described in two other infants with leprechaunism $(23,24)$ in whom the insulin resistance was also thought originally to be due to a post-receptor defect on the basis of normal insulin binding to fibroblasts, normal basal glucose transport, but absent insulin-stimulated glucose uptake. Further study in one of these patients (35) has revealed a qualitative defect of the insulin receptor characterized by temperature instability. In view of the normal acceleration of glucose uptake in response to insulin in our patient, a qualitative intrinsic receptor defect seems unlikely.

It also appears that our patient has a more general defect of cellular metabolism, since the normal increases in DNA synthesis (as measured by thymidine uptake into fibroblasts) elicited by insulin and also by exposure to fetal bovine serum, EGF, or hFGF were impaired in his fibroblasts. Kaplowitz and d'Ercole (19) have reported decreased thymidine uptake in response to insulin. EGF, FGF, and somatomedin-C as well as prolonged cell doubling time in the fibroblasts of an infant with leprechaunism who, as described in the preceding paragraph, had the same abnormality of glucose transport as our patient. In addition, the fibroblasts from their patient exhibited impaired uptake of the nonmetabolizable amino acid analogue aminoisobutyric acid in response to the growth factors insulin, EGF, somatomedin-C and multiple stimulating activity. With the exception of multiple stimulating activity, each of these growth factors has its own unique receptor. They postulated, therefore, a post-receptor defect involving a metabolic pathway affected in common by these growth factors and which may be expressed in multiple tissues to explain the prenatal growth retardation. It is possible that our patient has a similar post-receptor defect that is expressed as decreased growth factor-stimulated thymidine uptake and a prolonged doubling time. However, similarly altered growth properties have been observed in cells of diabetic patients (10) and may therefore represent a defect due to in vivo environmental factors rather than an intrinsic genetic defect. Impaired DNA 
synthesis occurs also in Werner's syndrome (34), in which insulin resistance is accompanied by growth retardation, hypogonadism, cataracts, and premature senescence (4). In this syndrome, there is evidence for a post-receptor metabolic defect (22) as well as an intracellular senescent factor responsible for abnormal cell growth (34). Thus, it remains unclear whether the altered growth properties of our patient's fibroblasts represent an intrinsic postreceptor defect or simply an acquired abnormality related to the diabetic state. These patients represent a formidable diagnostic challenge and, as in our case, pathogenesis is not always easily defined. This case report also underscores the need for further understanding of the heterogeneous group of clinical disorders recognized with insulin resistance due to receptor or post-receptor defects including leprechaunism, Werner's syndrome, lipoatrophic diabetes, and acanthosis nigricans (type A). There appears to be a continuum in phenotypic severity ranging from the serious life-threatening form of leprechaunism in the newborn period as we have previously reported $(29,32)$ to milder defects manifested by prenatal and postnatal growth retardation, hypogonadism, and secondary hepatomegaly as in the present case.

\section{REFERENCES AND NOTES}

1. Bala RM, Bhaumick B 1979 Radioimmunoassay of a basic somatomedin: comparison of various assay techniques and somatomedin levels in various sera. J Clin Endocrinol Metab 49:77

2. Bar RS, Harrison LC, Muggeo M, Gorden P, Kahn R, Roth 1979 Regulation of insulin receptors in normal and abnormal physiology in humans. Adv Intern Med 24:23

3. Berhanu P, Tsai P, Olefsky JM 1982 Insulin-stimulated glucose transport in cultured fibroblasts from normal and noninsulin-dependent (Type II) diabetic human subjects. J Clin Endocrinol Metab 55:1226

4. Epstein CJ, Martin GM, Schultz SL, Modulsky AG 1966 Werner's syndrome: a review of its symptomatology, natural history, pathologic features, genetics and relationship to the natural aging process. Medicine 45:177

5. Flier JS, Kahn CR, Roth J, Bar RS 1975 Antibodies that impair insulin receptor binding in an unusual diabetic syndrome with insulin resistance. Science 190:63

6. Gabbay KH, DeLuca K, Fisher JN, Jr, Mako ME, Rubenstein AH 1976 Familial hyperproinsulinemia: an autosomal dominant defect. N Engl J Med 294:911

7. Gambhir KK, Archer JA, Bradley CJ 1978 Characteristics of human erythrocyte insulin receptors. Diabetes 27:701

8. Gavin JR, III, Kahn, CR, Gorden P, Roth J, Neville DM, Jr 1975 Radioreceptor assay of insulin: comparison of plasma and pancreatic insulins and tor assay of insulin: comparison of plasma
proinsulin. J Clin Endocrinol Metab 41:438

9. Gillerot Y, Buez A, Hustin 1979 Leprechaunism (Donohue syndrome). A case with growth hormone deficiency. Acta Paediatr Belg 32:279

10. Goldstein S, Moeran EJ, Soeldner JS, Gleason RE, Barnett DM 1979 Diabetes mellitus and genetic prediabetes. Decreased replicative capacity of cultured skin fibroblasts. J Clin Invest 63:358

11. Greco AV, Bertoli A, Ghirlanda G, Manna R, Altomentel L, Rebuzzi AG 1980 Insulin resistance in liver cirrhosis: decreased insulin binding to circulating monocytes. Horm Metab Res 12:557

12. Greenwood FC, Hunter WM 1963 The preparation of ${ }^{131} \mathrm{I}$-labeled human growth hormone of high specific radioactivity. Biochem J 89:114

13. Guest GM 1953 The Mauriac syndrome: dwarfism, hepatomegaly and obesity with juvenile diabetes mellitus (editorial). Diabetes 2:415

14. Harley CB, Goldstein S, Posner BI, Guyda HJ 1980 Insulin-like peptides stimulate metabolism but not proliferation of human fibroblasts. Am J Physiol 69:E125

15. Hendricks SA, Lippe BM, Kaplan SA, Landow EM, Herts D, Scott M 1981 Insulin binding to erythrocytes of normal infants, children and adults: variation with age and sex. J Clin Endocrinol Metab 52:969
16. Husemann C, Johanson A, Varma M, Blizzard RM 1978 Congenital lipodystrophy: an endocrine study in three siblings: disorders of carbohydrate metabolism. J Pediatr 93:221

17. Johnston DG, George K, Alberti M, Wright R, Smith-Laing G, Stewart AM Sherlock S, Faber O, Binder C 1978 C-peptide and insulin in liver disease. Diabetes 27:201

18. Kahn CR, Podskalny JM 1980 Demonstration of a primary (genetic) defect in insulin receptors in fibroblasts from a patient with the syndrome of insulin resistance and acanthosis nigricans type A. J Clin Endocrinol Metab 50:1139

19. Kaplowitz PR, d'Ercole AJ 1982 Fibroblasts from a patient with leprechaunism are resistant to insulin, epidermal growth factor and somatomedin $\mathrm{C}$. J Clin Endocrinol Metab 55:741

20. Kappy MS, Plotnick L 1980 Erythrocyte insulin binding in obese children and adolescents. J Clin Endocrinol Metab 51:1440

21. Kellett JG, Tanaka T, Rowe JM, Shiu RPC, Friesen HG 1981 The characterization of growth factor activity in human brain. $J$ Biol Chem 256:54

22. Kissebah AH, Tulloch B, Vydelingum N 1979 Insulin resistance in Werner's syndrome: a post-receptor defect. Diabetes $28: 389$

23. Knight AB, Rechler MM, Romanus JA, Van Obberghen-Schilling EE, Nissley SP 1981 Insulin stimulated glucose incorporation and amino acid transport in fibroblasts with defective insulin receptors cultured from a patient with leprechaunism. Proc Natl Acad Sci USA 78:2554

24. Kobayashi M, Olefsky JM, Elders J, Mako ME, Given BD, Schedwie HK, Fiser RH, Hintz RL, Horner JA, Rubenstein AH 1978 Insulin resistance due to a defect distal to the insulin receptor (demonstration in a patient with leprechaunism). Proc Natl Acad Sci USA 75:3469

25. Muggeo M, Bar RS, Roth J, Kahn CR, Gorden P 1977 The insulin resistance of acromegaly: evidence for two alterations in the insulin receptor on circulating monocytes. J Clin Endocrinol Metab 48:17

26. Olefsky JM 1981 Lilly Lecture 1980. Insulin resistance and insulin action: an in vitro and in vivo perspective. Diabetes 30:148

27. Paulsen EP, Cortney JW, Duckworth WC 1979 Insulin resistance caused by massive degradation of subcutaneous insulin. Diabetes 28:640

28. Reed WB, Dexter R, Corley C, Fish C 1965 Congenital lipodystrophic disbetes with acanthosis nigricans. Arch Dermatol 91:326

29. Rosenberg AM, Haworth JC, deGroot GW, Trevenen CL, Rechler MM 1980 A case of leprechaunism with hyperinsulinism. Am J Dis Child 134:170

30. Savage CR, Jr, Cohen S 1972 Epidermal growth factor and a new derivative: rapid isolation procedure and biological and chemical characterization. $\mathrm{J}$ Biol Chem 247:7609

31. Scatchard G 1949 The attractions of proteins for small molecules and ions. Ann NY Acad Sci 51:660

32. Schilling EE, Rechler MM, Grunfeld C, Rosenberg AM 1979 Primary defect of insulin receptors in skin fibroblasts cultured from an infant with lepreof insulin receptors in skin fibroblasts cultured from an infant with
chaunism and insulin resistance. Proc Natl Acad Sci USA 76:5877

33. Tager H, Given B, Baldwin D, Mako M, Markese J, Rubenstein A, Olefsky J, Kobayashi M, Kolterman O, Poucher R 1979 A structurally abnormal insulin causing human diabetes. Nature 281:122

34. Tanaka K, Takano N, Okada Y, Humahara Y 1980 Role of nuclear and cytoplasmic environments in the retarded DNA synthesis in Werner syndrome cells. Exp Cell Res 127:185

35. Taylor SI, Roth J, Blizzard RM, Elders MJ 1981 Qualitative abnormalities in insulin binding in a patient with extreme insulin resistance: decreased sensitivity to alterations in temperature and $\mathrm{pH}$. Proc Natl Acad Sci USA 78:7157

36. Yalow RS, Berson SA 1961 Immunological aspect of insulin. Am J Med 31:882

37. This research was supported by the Medical Research Council of Canada and United States Department of Health and Human Services Grant R01-HDO7843-09.

38. The authors wish to express their appreciation to Dr. Nathan Wiseman for obtaining the skin specimens, to Dr. Roger James and Dr. David Goldberg for referring the patient, to Dr. John Gemmell for referring patient 1 , to Louise Dilling for her assistance in the clinical studies, and to June McDougald for typing the manuscript.

39. Requests for reprints should be addressed to: Dr. H. G. Friesen, Department of Physiology, University of Manitoba, 770 Bannatyne Avenue, Winnipeg, Manitoba, Canada R3E 0W3.

40. Received for publication April 10, 1983.

41. Accepted for publication September 20, 1983. 